\title{
Anna Górka-Strzałkowska
}

\section{Rodzic - trudny partner dla nauczyciela $Z$ badań nad innowacyjnym projektem w ursynowskiej szkole}

\section{Parent - difficult partner for the teacher From the research on an innovative project in the school in Ursynów}

\begin{abstract}
A B S T R A C T: The Primary School in Warsaw is one of the first in Poland, to adopt a program to promote best practices and discoveries in the field of education. By implementing the innovative project "Waking up school" teachers for one prioritized not doing homework. At the beginning, the project it aroused a great interest of teachers and parents. It saw great potential for educational change. The project had its supporters and opponents. On the one hand, there were words of support, recognition for innovation, idea, head teacher. On the other hand, conflicting goals and actions have become more and more apparent. The school turned to the Academy of Special Education for assistance in the activities of connecting parents, teachers, educational authorities and the local environment. The task was taken by PhD students and APS employees as a part of the methodology of quantitative and qualitative research. It was assumed that ultimately it will be several years research and action project. The first stage of which was the diagnosis of the situation. This article focuses on the first stage of research.
\end{abstract}

KEYWORDS: Innovation, research project, school, relations teacher-parent, empowerment school, collaboration teachers and parents, involment parental, change. 
STRESZCZENIE: Szkoła podstawowa na warszawskim Ursynowie jest jedną z pierwszych w Polsce, która przyjęła program promowania najlepszych praktyk i odkryć z obszaru edukacji. Realizując innowacyjny projekt "Budząca się szkoła", nauczyciele za jeden z priorytetów uznali niezadawanie prac domowych. Na początku projekt budził ogromne zainteresowanie zarówno wśród nauczycieli jak i rodziców. Widziano w nim ogromny potencjał do zmiany edukacyjnej. Projekt miał swoich zwolenników i przeciwników. Z jednej strony pojawiały się słowa wsparcia i uznania dla innowacji, z drugiej strony coraz wyraźniej do głosu dochodziły sprzeczne dążenia, narastało niezadowolenie i napięcia wśród różnych grup uczestniczących w projekcie. W tej sytuacji dyrekcja szkoły zwróciła się do Akademii Pedagogiki Specjalnej - z którą od dawna związana jest umową współpracy z propozycją diagnozy sytuacji i budowania sieci negocjacji i partnerstwa między szkołą a rodzicami. Zadanie to podjęła grupa doktorantów Akademii Pedagogiki Specjalnej w zakresie zajęć z metodologii badań jakościowych. Przyjęto, iż docelowo będą to kilkuletnie badania i działania, których pierwszym etapem stała się diagnoza sytuacji1. Niniejszy artykuł koncentruje się właśnie na tym etapie badań.

SŁOWA KLUCZOWE: Innowacja, projekt badawczy, szkoła, relacja rodzic-nauczyciel, upodmiotowienie szkoły, współpraca nauczyciele-rodzice, zaangażowanie rodzicielskie, zmiana.

\section{Innowacyjna szkoła, innowacyjny program}

Szkoła na Ursynowie to publiczna szkoła podstawowa, która jak wiele innych w Warszawie podejmuje różnorodne działania innowacyjne skierowane na polepszanie jakości pracy. Wyróżnia ją przede wszystkim to, iż w tych działaniach placówka szuka szerszych, trwalszych mechanizmów i sił rozwoju. Dostrzega znaczenie współpracy ze środowiskiem, stara się budować pozytywne relacje oparte na partnerstwie, na budzeniu i rozwijaniu sił i kapitałów społecznych pozwalających kształtować i rozwijać szkolną wspólnotę uczenia się. Działania wpisują się w koncepcję szkoły i jej rozwoju, która sięga zarówno do tradycyjnych stanowisk pedagogicznych, jak i do nowych inicjatyw i innowacji skierowanych na rozwój szkoły i budowanie w niej szerokiego środowiska uczenia się. Podstawą tego rozwoju w tradycyjnym znaczeniu są siły ludzkie i społeczne. Helena Radlińska akcentowała, iż siły te są fundamentalnym zasobem a także mechanizmem zmiany i rozwoju. Są atutem szkoły, pozytywnym kapitałem wygenerowanym przez lata pracy. Składają się na nie wysiłki dzieci, rodziców, nauczycieli, dyrekcji i całego środowiska. Są one powiększane przez tradycję lokalną, specjalne walory środowiska, a także uprzywilejowaną strukturę społeczną oraz wyjątkowe instytucje i organizacje funkcjonujące w środowisku szkoły (Radlińska 1935). Od wielu lat w obszarze pedagogiki społecznej prowadzone są badania nie tylko nad zasobami

1 Grupa pracowała pod kierunkiem prof. Barbary Smolińskiej-Theiss, dra Jacka Gralewskiego i dr Anny Górki-Strzałkowskiej. Tworzyli ją doktoranci: Alfred Tuci, Magdalena Roszak, Paulina Kamińska-Diduszko, Katarzyna Szolc, Jolanta Jancewicz, Jolanta Rybińska, Zuzanna Narkun, Konrad Pasikowski, Jolanta Bożyk. 
szkoły, ale także nad specjalnym modelem szkoły powiązanej ze środowiskiem (zob. Kowalski 1969; Modrzewski 1989; Radlińska 1935; Radziewicz-Winnicki 1996; Trempała 1976; Winiarski 1975). Jak bumerang powraca ciągle pytanie zarówno o szkolne siły społeczne i ludzkie, jak i o współczesne zróżnicowane i wielorakie mechanizmy rozwoju szkoły i oświaty w szerszych i węższych perspektywach społecznych.

$\mathrm{W}$ tradycyjnym znaczeniu koncentrujemy się na pytaniu jakimi siłami dysponuje szkoła, jakie ma zasoby, co jest jej atutem. Helena Radlińska wielokrotnie powtarzała, iż „pedagogikę społeczną interesuje przede wszystkim wzajemne oddziaływanie wpływów środowiska i przekształcających środowisko sił jednostek” (Radlińska 1935, s. 5). Pierwszy element tej definicji - „wpływy środowiska" - to zjawiska i procesy, które w określony sposób, pośrednio lub bezpośrednio, oddziałują na ludzi i wywołują określone relacje w środowisku. Jest to trudna relacja wzajemnych społecznych powiązań, współzależności występujących w różnych typach środowisk. Drugi element to „siły jednostek" (siły społeczne, siły ludzkie), celowe dążenia oparte na określonym systemie wartości, które utrwalone w postawach oddziałują na jednostkę lub grupę społeczną, łączą ludzi, budują wspólne dobro. Wpływ na kształtowanie i rozwijanie tych sił ma szeroko rozumiane wychowanie. Pedagogika społeczna za pomocą sił ludzkich chce budować „świat człowieka”, w którym respektowane są prawa człowieka (Theiss 2018, s. 14).

Pojęcie sił ludzkich oznacza dynamikę, możliwość zmiany, zarówno krytyczne jak i konstruktywne stanowisko w realnej sytuacji. Ich źródłem są rozwijane wartości, idee, tradycje i obyczaje. Mają charakter prospektywny, co oznacza, że przetwarzają teraźniejszość i budują przyszłość. Dzięki nim wychowanie wykracza poza ramy, tworzy więzi między jednostkami i grupami oraz rozwija poczucie wspólnotowości (Smolińska-Theiss, Theiss 2019, s. 340-341).

Jakimi siłami ludzkimi dysponuje szkoła na warszawskim Ursynowie? W jaki sposób szkoła buduje sieć wsparcia, negocjacji, partnerstwa $\mathrm{z}$ rodzicami? Jak rodzice i nauczyciele widzą swoją szkołę? Jakie rozwiązania społeczne, kulturowe, polityczne umożliwiają osiągnięcie sukcesu? Czy takie działania są możliwe. Dzięki jakim siłom szkoła ma gotowość do działania, współpracy czy partnerstwa? W jaki sposób nawiązuje się prawidłowa relacja szkołarodzice? Na te pytania staraliśmy się odpowiedzieć w podjętych badaniach.

\section{Teoria rozwoju szkoły - rama teoretyczna}

Ramą teoretyczną zainicjowanych badań jest teoria rozwoju szkoły (Nowosad 2003; Dalin 1985; Tillmann 1987). Szkoła stanowi specyficzną, skom- 
plikowaną organizację społeczną wpisaną w szerszy kontekst historyczny, polityczny, religijny i kulturowy. Jej działanie wyznaczają dwa wektory czasu. Z jednej strony, funkcjonowanie szkoły - stosownie do obowiązujących doktryn politycznych - służy reprodukcji teraźniejszości lub też konserwacji przeszłości. $Z$ drugiej strony, szkoła jest bardzo ważnym elementem i mechanizmem zmiany społecznej i rozwoju społecznego. Stąd fundamentalne, powracające wielekroć pytanie o siły sprawcze tego rozwoju. Jest to pytanie o władanie szkołą, o władzę nad szkołą, o model szkoły. We współczesnym społeczeństwie szkoła jest instytucją społeczną wpisaną w system demokratyczny, odzwierciedla i wzmacnia ten system. Demokracja i uspołecznienie to niezbywalne cechy szkoły. W polskich warunkach nabierają one szczególnego znaczenia. Zmiany społeczno-polityczne po 1989 roku usankcjonowane nową Konstytucją nadały szkole demokratyczny charakter, uspołeczniły ją, powiązały ze środowiskiem lokalnym i z rodziną, złamały monopol państwa. Relacje między państwem a szkołą mają odzwierciedlać demokratyczny ład społeczny oparty na zasadach solidarności i subsydiarności. Oznacza to, że szkoła staje w służbie dziecku, rodzinie, środowisku lokalnemu, a także narodowi i państwu. Jest powiązana ze społeczeństwem, z polityką, kulturą, ekonomią, religią. Ma ramy społeczne i prawne. Ten przyjęty w Polsce po 1989 roku model szkoły budzi coraz więcej pytań i wątpliwości (zob. Pilch 1995; Śliwerski 2008; Mendel 1999; Czerepaniak-Walczak 2010). Dotyczą one przede wszystkim perspektywy makro, koncentrują się na relacjach między państwem a szkołą. Nie odrzucając tej perspektywy pedagogika społeczna koncentruje swoje zainteresowania na węższej perspektywie. Stawia pytania nie tyle o system, ale o konkretne szkoły. Jak to się dzieje, że w zunifikowanym systemie, w którym obowiązują wspólne podstawy programowe, jednakowe standardy kształcenia, pracy i płacy nauczycielskiej jedne szkoły osiągają znakomite efekty, inne daleko od nich odbiegają? Co to oznacza dla konkretnej szkoły, co to oznacza dla jej rozwoju? Takie pytania odwołują się do ważnej, nośnej teorii oddolnego rozwoju szkoły. Nie jest ona nowa. Rozwinęła się zwłaszcza w Niemczech w połowie lat 80. ubiegłego stulecia. Stała się teoretyczną i praktyczną odpowiedzią na wątpliwe efekty i nieudane reformy oświatowe przeprowadzone w tamtych czasach w wielu krajach. Rozwój szkoły oznacza rozwój szkoły od środka, dzięki wpływom sił ludzkich, dzięki jej rozbudowanym kapitałom i zasobom. Zgodnie $\mathrm{z}$ teorią oddolnego rozwoju szkoła, tak jak inne organizacje, musi sobie radzić zarówno z zewnętrzną, jak i wewnętrzną presją wpływów. Dzięki zaangażowaniu rodzicielskiemu, współpracy z rodzicami buduje swoją siłę i pozycję w środowisku. Szuka partnerów, zjednuje różne grupy i organizacje społeczne, przyciąga liderów lokalnych. Podejmuje wspól- 
nie różne oddolne inicjatywy i projekty, które wzmacniają szkołę, konsolidują także społeczność lokalną.

Jak podaje Klaus Tillmann (1987) prekursorem teorii szkoły był Wilhelm Dilthey. Obszarem zainteresowań była szkoła jako instytucja w kontekście historycznym, politycznym, społecznym i kulturowym. Tillmann uważa, że „zależność pomiędzy szkołą jako instytucją a systemem społecznym stanowi podstawowy obszar teorii szkoły". Kluczowym momentem jest poznanie zmian zachodzących między państwowo-społecznymi a lokalnymi wyznacznikami funkcjonowania szkoły. W tym znaczeniu teorie rozwoju szkoły łączą się z teoriami zmiany społecznej (Tillmann 1987, s. 8).

W Polsce teorie rozwoju szkoły opracowała Inetta Nowosad (2003). Jej zdaniem zmiana następuje dzięki nowej wiedzy, ale często sama wiedza nie wystarcza. Społeczeństwo musi uznać, że zmiana jest potrzebna i wiedzieć co wniesie nowego (Nowosad 2003, s. 60). W definicji zmiany społecznej, jak podaje Andrzej Radziewicz-Winnicki, „występują zarówno przeobrażenia przypadkowe i drobne, pozornie nieistotne, zachodzące w postawach jednostek, mniej ważne dla egzystencji grupy w wielu obszarach jej życia zbiorowego, jak również zmiany trwałe, te szczególnie istotne, przekształcające radykalnie dotychczasowe funkcje jednostek, grup społecznych w danej strukturze (Radziewicz-Winnicki 1996, s. 117-118).

Potencjał zmiany w codzienności szkolnej kieruje się ku nauczycielowi, który jest promotorem działań zbliżających szkołę do realnych potrzeb świata współczesnego. Uczestnictwo $\mathrm{w}$ zmianie nie kończy się wraz z jej wprowadzeniem, ponieważ szkoła nieustannie się rozwija, oddziałując na innych, prowokując do zmiany. Idea zmiany stała się przesłaniem reformowanej szkoły i wyzwaniem dla nauczyciela-wychowawcy, który nadawał jej tempo i kierunek. Nowa idea zmiany niesie ze sobą pojęcie innowacji. Inicjowanie procesu przemian rodzi nowe role społeczne, nowe potrzeby, oczekiwania i aspiracje. Pojawiają osoby, które chcą angażować się w coś nowego, poszerzać horyzonty, badać nowe tereny, zachęcać swoich współpracowników do tworzenia społeczności zwolenników innowacji pedagogicznych (Nowosad 2003).

Michael Fullan wskazuje na cztery grupy czynników, które mają wpływ na wdrożenie innowacji pedagogicznych. Pierwsza koncentruje się na właściwościach innowacji - czy jest zapotrzebowanie na tę innowację?, jaka jest jej użyteczność praktyczna? Druga grupa dotyczy właściwości okręgu szkolnego - czy były wcześniejsze próby podejmowania tej innowacji?, czy jest poparcie kuratorium i zaangażowanie w innowację?, czy nauczyciele są odpowiednio przeszkoleni w tej dziedzinie?, jaki jest przekaz informacji? Trzecia grupa to właściwości szkoły - jakie są predyspozycje kierownicze, osobowościowe 
i zawodowe dyrektora?, jaki jest stosunek nauczycieli do wprowadzania innowacji?, jakie są oczekiwania i potrzeby uczniów danej szkoły? Ostatnia grupa czynników koncentruje się na właściwościach czynników zewnętrznych - jaką rolę odgrywają agendy rządowe w realizacji innowacji?, czy szkoła pozyskuje fundusze $\mathrm{z}$ zewnątrz na wprowadzenie i realizację projektu innowacyjnego? (Fullan 1991).

W praktyce proces wprowadzania innowacji pedagogicznych podyktowany jest zmianami społeczno-ekonomicznymi i politycznymi, które wprowadzają chaos informacyjny, napięcie i przeciążenie. Przykładem są nowe przepisy prawne opracowane po 1 września 2017 r., które dają szkole względną autonomię działania. Innowacje pedagogiczne nie muszą być zatwierdzana przez organ prowadzący, tzn. kuratorium. Ustawodawca daje możliwość dyrektorowi szkoły na podejmowanie innowacji, które odpowiadają na aktualne potrzeby i oczekiwania uczniów. W tej perspektywie innowacje szkolne, rozwój szkoły, są działaniem oddolnym, prowadzonym przez szkołę i jej różnych partnerów. Pieczę nad nimi i odpowiedzialność prawną sprawuje dyrektor szkoły.

Inetta Nowosad wyraźnie podkreśla, iż rozwój szkoły buduje specjalny typ szkolnej wspólnoty, tworzy model szkoły jako organizacji uczącej się (2003). Co to znaczy? Roman Schulz zwraca uwagę na trzy komponenty szkoły jako organizacji. Pierwszy dotyczy ról zawodowych i społecznych pełnionych przez członków społeczności szkolnej. Są one usankcjonowane prawnie, społecznie, kulturowo. Nauczyciel i uczniowie wiedzą (powinni wiedzieć), co to znaczy być uczniem, co to znaczy być nauczycielem, jak pełnić te role. Drugi organizacyjny komponent szkoły łączy funkcjonalnie różne, ale komplementarne, elementy szkoły, np. programy, zasady oceniania uczniów, przygotowanie zawodowe nauczycieli. Trzeci instytucjonalny komponent szkoły odnosi się do szerszego układu (Schulz 1992, s. 32) i reguluje programowe, prawne, społeczne ramy funkcjonowania szkoły w sytemie oświaty.

Aby zrozumieć funkcjonowanie szkoły jako organizacji należy zwrócić również uwagę na jej strukturę. Tak jak inne organizacje szkoła musi sobie radzić zarówno z zewnętrzną, jak i wewnętrzną presją wpływów ze środowiska. Szkoła jako organizacja ucząca się charakteryzuje się pięcioma istotnymi wymiarami szkoły, którymi są: środowisko, wartości, struktura, relacje międzyludzkie i strategie. $\mathrm{W}$ tym wymiarze środowisko rozumiane jest jako najbliższe otoczenie szkoły, jak i społeczeństwo ogółem. Dotyczy wszystkich instytucji, z którymi szkoła utrzymuje kontakt, aby osiągnąć zamierzone cele. Zawierają się tu administracyjne powiązania $\mathrm{z}$ władzami, zwierzchnikami szkoły (kuratorium oświaty, urząd miasta, ministerstwo oświaty), współpraca $z$ instytucjami odpowiedzialnymi za dzieci i młodzież, jak również nieformalne kontakty z rodziną, biznesem 
i lokalną społecznością (Nowosad 2003, s. 76-77). Jeśli szkoła stara się spełniać oczekiwania rodziców, jest otwarta na propozycje ze środowiska, współpracuje z lokalnymi jednostkami, ma duże pole do działania i budowania swojej kultury. Jeśli jednak narusza normy, tradycje wykraczające poza normy prawidłowego funkcjonowania, napotyka opór. Pojawia się bariera komunikacyjna szkoły z rodzicami, ze środowiskiem lokalnym, a także $\mathrm{z}$ władzami oświatowymi.

Wartości szkoły wyrażone są w ideologiach, teorii uczenia się i wychowania, w obowiązujących regułach i normach. Odnoszą się do celów sformułowanych w misji szkoły, jej programie, statucie. Odnoszą się również do norm ustalonych przez dyrekcję szkoły, nauczycieli, uczniów i innych członków społeczności szkolnej. Nie zawsze są one spójne. Niektóre są ze sobą w konflikcie, inne są ukrywane. Zadaniem szkoły jest wypracowanie wspólnych obszarów wartości oraz stworzenie na ich podstawie obowiązujących norm funkcjonowania w środowisku szkolnym. Kolejny wymieniany element dotyczy struktury szkoły. Pokazuje on jak szkoła jest zorganizowana, jak rozdzielane są zadania i jak wyglądają formalne struktury podejmowania decyzji oraz struktura komunikacyjna (Nowosad 2003, s. 78). Struktura decyzji określa kto, o czym decyduje. Struktura zadań obejmuje podział obowiązków i pracy wśród nauczycieli i uczniów. Natomiast struktura komunikacyjna eksponuje osoby i grupy, które wchodzą $\mathrm{w}$ relacje ze względu na obszar odpowiedzialności, zadań jakie mają do wykonania. Relacje dotyczą stosunków międzyludzkich panujących w szkole, do ich istoty, częstotliwości i jakości. Ujmuje się je w nieformalną organizację (władzę, wpływy, współpracę i normy poszczególnych osób lub grup), jak również bierze się pod uwagę te czynniki, które decydują o klimacie szkoły (motywacja, zadowolenie, zaufanie, pomoc, współpraca). Znaczenie ma także emocjonalne przywiązanie do szkoły oraz jakość relacji międzyludzkich rozumiane jako zdolność rozwiązywania konfliktów. Strategie dotyczą rodzaju i sposobu kierowania szkołą, podejmowania decyzji i kontroli jakości. Ważne jest czy szkoła nagradza kreatywność, uczy się przez nowe doświadczenia, ponieważ to warunkuje jakość kształcenia (Nowosad 2003, s. 80). Koncepcja Schulza akcentuje przede wszystkim formalne ramy funkcjonowania szkoły. Można w niej dostrzec próbę racjonalizacji zarządzania szkołą. Bliska jest także współczesnym stanowiskom rozwijania szkolnego managementu.

\section{Partnerstwo rodziny i szkoły - trudny program społeczny i badawczy}

Teoria rozwoju szkoły nie odrzuca widocznych, zwłaszcza w Ameryce, prób komercjalizacji szkolnictwa. Zwraca jednak uwagę na inne elementy. Roz- 
wój szkoły jest rezultatem oddolnych inicjatyw podejmowanych w szkole. Są one realizowane dzięki wsparciu i zaangażowaniu różnych podmiotów społecznych, a zwłaszcza rodziców.

We współczesnym świecie zaangażowanie rodziców w edukację własnych dzieci jest traktowane jako indywidualne prawo rodziców jak oraz społeczna konieczność. Szkoły nie są w stanie wywiązywać się ze swoich zadań edukacyjnych bez współpracy z rodzicami. Zaangażowanie rodziców rozumiane jest jako wszelkie aktywne działanie na rzecz wspierania rozwoju emocjonalnego i społecznego dziecka. Na tak rozumianą aktywność składają się szeroko rozumiane działania rodzicielskie (Szumski, Karwowski 2015). Zaangażowanie odnosi się zawsze do kogoś lub czegoś. Jego zewnętrzną manifestacją jest określone działanie wyrażające uznanie słuszności danej kwestii. Zaangażowanie wskazuje na utożsamianie się $\mathrm{z}$ danym obszarem, włączanie go $\mathrm{w}$ sferę zainteresowań. Świadczy o silnej, a zarazem trwałej motywacji do kontynuowania aktywności, koncentracji na niej. Obszar zaangażowania reprezentuje wyznawane przez jednostkę wartości i ideały. Zaangażowanie w rodzicielstwo stanowi nabytą skłonność do długotrwałego skoncentrowania aktywności i przeżyć z nią związanych na roli matki/ojca, która obejmuje zogniskowanie aktywności osoby dorosłej w wymiarze intelektualnym, emocjonalnym, behawioralnym i ewaluatywnym. Wyrazem pełnego zaangażowania jest określony sposób myślenia, przeżywania, wartościowania i działania wobec dziecka, włączając w to gotowość rodziców do zmiany aktywności w zależności od fazy rozwojowej potomstwa. Jak wskazują badania, rodzice deklarują zaangażowanie, ale nie zawsze to realizują (Bakiera 2013, s. 21-22). Maria Fishel i Lucila Ramirez (2005) zakładają, że rodzicielskie zaangażowanie odnosi się do partycypacji rodziców w edukacji swoich dzieci i ma na celu wspomaganie ich sukcesu szkolnego i społecznego. Zdaniem Nancy Hill i Diana Tyson (2009) zaangażowanie polega na interakcjach rodziców i szkoły oraz ze swoimi dziećmi w celu zwiększania szans dzieci na sukces w uczeniu się. Joyce Epstein (1995) uważa, że zaangażowanie należy rozpatrywać z trzech wzajemnie ze sobą powiązanych perspektyw: szkoły, domu i społeczności lokalnej. Wyróżnia sześć rodzajów zaangażowania: rodzicielstwo czyli zobowiązanie rodziców do stwarzania korzystnych warunków uczenia się w domu, komunikacja jako porozumiewanie się rodziców ze szkołą w sprawach dotyczących programu nauczania oraz postępów ucznia $\mathrm{w}$ nauce, wolontariat jako dobrowolne uczestnictwo rodziców w działania szkoły, nauka domowa czyli porozumiewanie się rodziców ze szkołą dotyczące uczenia się w domu, współdecydowanie czyli zaangażowanie rodziców w procesy zarządzania szkołą i podejmowania decyzji, współpraca rodziców ze społecznością lokalną mającą na celu stwarzanie warunków 
do lepszego uczenia się dzieci. Epstein mówiąc o zaangażowaniu, ma na myśli partnerski charakter relacji rodzina-szkoła-społeczność lokalna. Edukacyjne partnerstwo odnosi się do relacji wokół dziecka-ucznia, angażującej jego rodzinę, szkołę oraz lokalne otoczenie. Jest skoncentrowane na współpracy, wzajemnym zaufaniu i poczuciu posiadania wspólnego dobra.

Partnerstwo rodziny i szkoły oznacza symetryczne relacje między oboma partnerami. Można je jednak analizować z dwu różnych perspektyw. Przez wiele lat dominowała perspektywa szkolna. Na plan pierwszy wysuwali się nauczyciele współpracujący $\mathrm{z}$ rodziną. $\mathrm{W}$ dzisiejszych badaniach edukacyjnych coraz wyraźniej wybrzmiewa stanowisko rodzicielskie. Powstają międzynarodowe sieci i grupy badawcze zajmujące się rodzicielstwem w perspektywie zmian edukacyjnych (ERNAPE). Rodzice postrzegani są jako ważny partner dla szkoły, jako kontrahenci i znacząca społeczna siła nacisku wpływająca na polityczne decyzje oświatowe. Na forum akademickim akcentowane są pytania o ideologie oświatowe, o teorie, a także o metodologię badań nad relacjami: rodzina-szkoła. W środowisku naukowym poszukuje się wskaźników pozwalających analizować partnerstwo rodziny i szkoły. Wymienia się wśród nich: wskaźniki behawioralne - dotyczące partnerskich działań; wskaźniki związane $\mathrm{z}$ relacjami poznawczo-emocjonalnymi wobec szkoły $\mathrm{w}$ tym: $\mathrm{z}$ zainteresowaniem szkołą, gotowością do współdziałania $\mathrm{z}$ nią. Ostatnią grupę stanowią wskaźniki pokazujące normatywne wzory wychowania dzieci, funkcjonowania szkoły, miejsca edukacji w społeczeństwie.

Partnerstwo powinno skupić się na problemach szkolnych, dostarczać satysfakcji osobom niezaangażowanym oraz kreować strukturę umożliwiającą tworzenie oddolnych inicjatyw i pomysłów (Mendel 2002, s. 53). Przykładem takiej inicjatywy jest innowacja pedagogiczna wprowadzona przez ursynowską szkołę, znana w środowisku jako ograniczenie zadawania prac domowych, w rzeczywistości będąca programem znacznie bogatszym, obejmującym: wstęp, założenia ogólne, cele innowacji, metody i formy, przewidywane osiągnięcia, tematykę zajęć, ewaluację, spodziewane efekty i podsumowanie. Określono główne założenia pracy innowacyjnej, cele ogólne i szczegółowe. Ustalono metody i formy pracy z uczniami i rodzicami. Przewidziano korzyści z wdrożenia danego projektu innowacyjnego. Określono spodziewane efekty jakie osiągnie szkoła, aby podnieść jakość pracy oraz promocję w środowisku lokalnym a nawet ogólnopolskim.

W założeniu program innowacyjny miał przynosić korzystną zmianę dla instytucji, pobudzać jej rozwój, angażować uczniów, rodziców nauczycieli i uczniów do wspólnej aktywności. Stał się również dużym wyzwaniem i nadzieją dla nauczycieli, rodziców i uczniów. A jednak w trakcie jego realiza- 
cji pojawiły się kłopoty, sprzeczne oczekiwania, nieadekwatne oceny zgłaszane przez różnych uczestników projektu.

\section{Program badań \\ - wspólnota myślenia, gotowość do wspólnego działania}

Dyrekcja szkoły zwróciła się do Akademii Pedagogiki Specjalnej - z którą od dawna związana jest umową współpracy - z propozycją diagnozy sytuacji. Pojawiły się pytania o szkolną wspólnotę uczenia się, o kapitał społeczny pozwalający budować programy innowacyjne, o gotowość, poczucie sprawczości i współodpowiedzialność nauczycieli, rodziców, a także uczniów za powodzenie i efekty programu.

Przyjęto, iż będą to kilkuletnie badania praktyczne (badania przez działanie) typu action research. Pierwszym etapem stała się diagnoza sytuacji przygotowana przez doktorantów Akademii Pedagogiki Specjalnej podczas zajęć z metodologii badań społecznych. Niniejszy artykuł koncentruje się na tym pierwszy etapie badań. Był to ilościowy pomiar skoncentrowany na pytaniach na ile nauczyciele i rodzice prezentują zbieżne i rozbieżne modele kształcenia i funkcjonowania szkoły, na ile obie strony zainteresowane są programem innowacyjnym i są gotowe do współdziałania w jego realizacji.

Badania takie przeprowadzone zostały za pomocą dwóch obszernych kwestionariuszy skierowanych do nauczycieli i rodziców. Zawierały takie same lub podobne pytania. Odpowiedzi na nie umieszono na skali 5- lub 7-stopniowej. Przedstawione poniżej wyniki badań ograniczają się do jednego z 12 pytań zawierającego 40 możliwych, wyskalowanych odpowiedzi. Pokazują one nauczycielskie i rodzicielskie modele i stanowiska związane $\mathrm{z}$ edukacją i funkcjonowaniem szkoły. Odzwierciedlają typy myślenia, a także doświadczenia zawodowe i życiowe związane ze szkołą. Co najważniejsze, pozwalają budować przesłanki o partnerstwie i możliwej wspólnocie myślenia i działania skierowanego na rozwój szkoły.

W badaniu wzięło udział 82 nauczycieli zatrudnionych w ursynowskiej szkole, $\mathrm{z}$ których $41,5 \%(\mathrm{n}=34)$ stanowili nauczyciele klas $1-3$, a $58,5 \%(\mathrm{n}=48)$ nauczyciele klas $4-8$. Przeważały kobiety $-85,4 \%$. Prawie $40 \%$ badanych zatrudnionych było na stanowisku nauczyciela kontraktowego, co piąty był nauczycielem mianowanym. Nauczyciele stażyści stanowili $27,2 \%$ badanych, statusem nauczyciela dyplomowanego legitymowało się 13,6\% badanych. Jest to struktura zawodowa odbiegająca od ogólnego stanu polskiego nauczycielstwa. Odsłania zjawisko charakterystyczne dla stolicy i wielkich miast. Pokazuje jak wiele osób wchodzi i szybko odchodzi z zawodu nauczycielskiego. Średni czas 
pracy nauczycieli w badanej szkole wynosi 5,74 roku, ale co drugi pracuje w niej od dwóch lat, a co trzeci od roku. Najliczniejszą grupę badanych tworzyli nauczyciele edukacji wczesnoszkolnej $(26,1 \%)$, na kolejnym miejscu plasowali się nauczyciele języków obcych oraz poloniści (razem 27,5\%), a następnie nauczyciele wychowani fizycznego i wychowawcy świetlicowi.

Kwestionariusze pomiaru wypełniło 262 rodziców lub opiekunów prawnych, w większości matki (78,25\%). Była to grupa dość jednorodna wiekowo. Średnia wieku dla wszystkich rodziców wynosiła 41,23, mediana niewiele mniej (41.0). Ponad 90\% rodziców miało wykształcenie wyższe, 60,7\% wychowywało jedno dziecko, 37\% dwoje. Byli to najczęściej uczniowie klas młodszych. Taka struktura rodziny, wieku i wykształcenia rodziców daleka jest od statystycznego obrazu polskiej szkoły. Odsłania typowy obraz wielkomiejskich osiedli mieszkaniowych skupiających klasę średnią. Przytoczone proste dane socjograficzne pokazują, iż trudno jest badać polską szkołę en block. Zróżnicowania środowiskowe są ogromne i po raz kolejny potwierdzają zasadność badań w perspektywie mikro- lub mezo-.

Podstawą analizy były oceny rodziców i nauczycieli wyrażone na siedmiostopniowej skali dotyczące nauczania i wychowani dzieci, funkcjonowania szkoły oraz programu innowacyjnego szkoły a dokładniej jego najbardziej nośnego elementu jakim było niezadawanie prac domowych.

Na początku analiz porównano średnie ocen poglądów rodziców i nauczycieli. Porównania przeprowadzono parami, wykorzystując test $t$ dla prób zależnych. Następnie zmierzono siłę efektu (d Cohena), którą interpretuje się w następujący sposób:

$\mathrm{d}<0,20$ - efekt bardzo słaby,

d $>0,20$ - efekt słaby,

$\mathrm{d}>0,5$ - efekt o przeciętnej sile,

$\mathrm{d}>0,8$ - efekt silny.

Badania pokazały, że stanowiska i oceny rodziców i nauczycieli nie są tak odległe od siebie. $\mathrm{Z}$ wieloma $\mathrm{z}$ nich zgadzają się zarówno nauczyciele, jak i rodzice. Analizy statystyczne pozwoliły wyłonić trzy grupy danych. Najliczniejszą grupą okazały się stanowiska i oceny zbieżne dla rodziców i nauczycieli. Jak pokazały badania nie ma w nich istotnych statystycznie różnic.

Tabela 1. Stanowiska wspólne dla rodziców i nauczycieli

\begin{tabular}{|l|c|c|c|c|c|c|c|}
\hline \multirow{2}{*}{ Stwierdzenie } & \multicolumn{2}{|c|}{ A: Rodzice } & \multicolumn{2}{c|}{ B: Nauczyciele } & \multicolumn{3}{|c|}{ Porównanie średnich } \\
\cline { 2 - 8 } & $\mathrm{M}$ & SD & M & SD & $F(1 ; 334)$ & Siła efektu $d$ & Relacja A-B \\
\hline $\begin{array}{l}\text { 1. Rodzice i nauczyciele są partnera- } \\
\text { mi w wychowaniu dzieci. }\end{array}$ & 4,27 & 0,76 & 4,26 & 0,72 & 0,005 (ni) & 0,01 & \\
\hline
\end{tabular}


Anna Górka-Strzałkowska

\begin{tabular}{|c|c|c|c|c|c|c|c|}
\hline \multirow{2}{*}{ Stwierdzenie } & \multicolumn{2}{|c|}{ A: Rodzice } & \multicolumn{2}{|c|}{ B: Nauczyciele } & \multicolumn{3}{|c|}{ Porównanie średnich } \\
\hline & $\mathrm{M}$ & SD & $M$ & SD & $F(1 ; 334)$ & Siła efektu $d$ & Relacja A-B \\
\hline $\begin{array}{l}\text { 2. Bez dyscypliny na lekcji nie ma } \\
\text { uczenia się. }\end{array}$ & 3,87 & 1,13 & 3,88 & 1,15 & 0,003 (ni) & 0,01 & \\
\hline $\begin{array}{l}\text { 3. Z autorytetem nauczyciela się nie } \\
\text { dyskutuje. }\end{array}$ & 3,01 & 1,23 & 3,00 & 1,24 & 0,003 (ni) & 0,01 & \\
\hline $\begin{array}{l}\text { 4. Szkoła jest od nauki a nie od za- } \\
\text { bawy. }\end{array}$ & 2,66 & 1,16 & 2,65 & 1,27 & 0,002 (ni) & 0,01 & \\
\hline $\begin{array}{l}\text { 5. Dyrektor jest liderem i odpowiada } \\
\text { za wszystko co dzieje się w szkole. }\end{array}$ & 3,96 & 0,92 & 3,98 & 1,07 & 0,01 (ni) & 0,01 & \\
\hline $\begin{array}{l}\text { 6. Szkoła jest instytucją, która uczy } \\
\text { porządku i hierarchii. }\end{array}$ & 3,56 & 1,04 & 3,57 & 1,16 & 0,01 (ni) & 0,01 & \\
\hline $\begin{array}{l}\text { 7. Rodzice boją się nauczycieli, na- } \\
\text { uczyciele boją się rodziców. }\end{array}$ & 2,15 & 1,14 & 2,14 & 1,22 & 0,02 (ni) & 0,02 & \\
\hline 8. Szkoła uczy - rodzina wychowuje. & 3,68 & 1,28 & 3,73 & 1,32 & 0,10 (ni) & 0,04 & \\
\hline $\begin{array}{l}\text { 9. Obowiązkiem rodzica jest poma- } \\
\text { gać dziecku w odrabianiu lekcji. }\end{array}$ & 3,26 & 1,23 & 3,31 & 1,17 & 0,08 (ni) & 0,04 & \\
\hline $\begin{array}{l}\text { 10. Uczeń powinien podporządko- } \\
\text { wać się oczekiwaniom nauczyciela. }\end{array}$ & 3,46 & 1,02 & 3,42 & 1,04 & 0,08 (ni) & 0,04 & \\
\hline $\begin{array}{l}\text { 11. Szkoła powinna przede wszyst- } \\
\text { kim nauczać. }\end{array}$ & 3,68 & 1,17 & 3,54 & 1,29 & 0,75 (ni) & 0,06 & \\
\hline $\begin{array}{l}\text { 12. Za moich czasów w szkole pa- } \\
\text { nowała dyscyplina i porządek i po co } \\
\text { to zmieniać? }\end{array}$ & 2,76 & 1,24 & 2,65 & 1,32 & 0,49 (ni) & 0,09 & \\
\hline $\begin{array}{l}\text { 13. Szkoła powinna respektować } \\
\text { prawa ucznia. }\end{array}$ & 4,61 & 0,69 & 4,69 & 0,58 & 0,83 (ni) & 0,12 & \\
\hline $\begin{array}{l}\text { 14. Nie ma dobrej szkoły bez do- } \\
\text { brych relacji między nauczycielami. }\end{array}$ & 4,43 & 0,68 & 4,54 & 0,76 & 1,64 (ni) & 0,16 & \\
\hline $\begin{array}{l}\text { 15. Szkoła nie jest w stanie zreali- } \\
\text { zować wszystkich stawianych przed } \\
\text { nią zadań. }\end{array}$ & 3,49 & 0,98 & 3,67 & 1,10 & 1,80 (ni) & 0,17 & \\
\hline $\begin{array}{l}\text { 16. Rodzice powinni włączyć się do } \\
\text { programu szkoły. }\end{array}$ & 3,48 & 0,92 & 3,30 & 1,12 & 1,97 (ni) & 0,18 & \\
\hline $\begin{array}{l}\text { 17. Uczeń nie może dyskutować } \\
\text { z poglądami nauczyciela. }\end{array}$ & 2,69 & 1,20 & 2,46 & 1,28 & 2,18 (ni) & 0,19 & \\
\hline $\begin{array}{l}\text { 18. Szkoła powinna przede wszyst- } \\
\text { kim realizować program nauczania, } \\
\text { a nie rozpraszać się na dodatkowe } \\
\text { zadania. }\end{array}$ & 2,82 & 1,25 & 2,58 & 1,41 & 2,20 (ni) & 0,19 & \\
\hline $\begin{array}{l}\text { 19. Nic nie dzieje się w szkole bez } \\
\text { zgody dyrektora. }\end{array}$ & 3,62 & 0,98 & 3,84 & 1,13 & 2,85 (ni) & 0,21 & \\
\hline $\begin{array}{l}\text { 20. Rodzice i nauczyciele są part- } \\
\text { nerami w procesie nauczania dzieci. }\end{array}$ & 4,30 & 0,84 & 4,48 & 0,76 & 2,95 (ni) & 0,22 & \\
\hline $\begin{array}{l}\text { 21. Uczeń uczy się dla siebie, nie } \\
\text { dla ocen. }\end{array}$ & 4,14 & 0,97 & 4,36 & 0,95 & 3,19 (ni) & 0,23 & \\
\hline $\begin{array}{l}\text { 22. To rodzic decyduje o swoim } \\
\text { dziecku. }\end{array}$ & 4,17 & 0,90 & 3,96 & 0,94 & 3,20 (ni) & 0,23 & \\
\hline $\begin{array}{l}\text { 23. Szkoła jest instytucją w służbie } \\
\text { rodziny. }\end{array}$ & 3,63 & 1,07 & 3,37 & 1,23 & 3,23 (ni) & 0,23 & \\
\hline
\end{tabular}


Rodzic - trudny partner dla nauczyciela...

\begin{tabular}{|l|c|c|c|c|c|c|c|}
\hline \multirow{2}{*}{ Stwierdzenie } & \multicolumn{2}{|c|}{ A: Rodzice } & \multicolumn{2}{c|}{ B: Nauczciele } & \multicolumn{3}{|c|}{ Porównanie średnich } \\
\cline { 2 - 8 } & $\mathrm{M}$ & $\mathrm{SD}$ & $\mathrm{M}$ & $\mathrm{SD}$ & $F(1 ; 334)$ & Sita efektu $d$ & Relacja A-B \\
\hline $\begin{array}{l}\text { 24. Jeśli uczeń nie zrozumiał lekcji } \\
\text { to praca domowa mu w niczym nie } \\
\text { pomoże. }\end{array}$ & 3,31 & 1,40 & 3,63 & 1,23 & 3,32 (ni) & 0,23 & \\
\hline $\begin{array}{l}\text { 25. Uczén uczy się nie tylko od na- } \\
\text { uczyciela ale również od kolegów. }\end{array}$ & 4,07 & 1,00 & 4,51 & 0,74 & $13,33^{\star \star \star}$ & 0,46 & \\
\hline $\begin{array}{l}\text { 26. Prace domowe były, są i dlacze- } \\
\text { go miało by ich nie być? }\end{array}$ & 3,05 & 1,28 & 2,29 & 1,14 & $22,53^{\star \star \star}$ & 0,60 & \\
\hline
\end{tabular}

Legenda: $\mathrm{ni}-p>0,05 ;{ }^{*} p<0,05 ;{ }^{* \star} p<0,01$; ${ }^{* \star} p<0,01$.

Źródło: opracowanie własne.

Drugą grupę stanowią wypowiedzi, w których o sile zależności decydują nauczyciele. Są to zdania wyrażające dydaktyczne zasady kształcenia i funkcjonowania szkoły. Odnoszą się do ucznia, do pracy nauczycielskiej, wskazują na potrzebę indywidualizacji procesu kształcenia i uczenia się, jak i pracy zespołowej. Charakterystyczne, iż nauczyciele - podobnie jak pokazano wyżej - deklarują postawy asekuracyjne. Twierdzą, iż rodzice nie muszą wiedzieć wszystkiego o szkole. Największą siłę efektu wyrażającą związek między ocenami nauczycieli i rodziców miało zdanie, iż w szkole ważniejsza jest dobra atmosfera, niż wyniki w nauce. To stereotypowe stanowisko pokazuje, iż w oczywisty sposób szkoła jest dla nauczycieli przede wszystkim miejscem pracy. Siłę efektu wypowiedzi nauczycieli i rodziców pokazuje tabela 2.

Tabela 2. Stanowiska bardziej znaczące dla nauczycieli

\begin{tabular}{|c|c|c|c|c|c|c|c|}
\hline \multirow{2}{*}{ Stwierdzenie: } & \multicolumn{2}{|c|}{ A: Rodzice } & \multicolumn{2}{|c|}{ B: Nauczyciele } & \multicolumn{3}{|c|}{ Porównanie średnich } \\
\hline & $M$ & SD & $M$ & SD & $F(1 ; 334)$ & Siła efektu $d$ & Relacja A-B \\
\hline $\begin{array}{l}\text { 1. Klasa szkolna to zbiór indywidual- } \\
\text { ności. }\end{array}$ & 4,49 & 0,74 & 4,68 & 0,59 & $4,46^{*}$ & 0,27 & $B>A$ \\
\hline $\begin{array}{l}\text { 2. Nie wszyscy uczniowie muszą się } \\
\text { uczyć tego samego i w takim samym } \\
\text { tempie. }\end{array}$ & 4,30 & 0,87 & 4,54 & 0,87 & $4,97^{*}$ & 0,28 & $B>A$ \\
\hline $\begin{array}{l}\text { 3. Wskazywanie mocnych stron ucznia } \\
\text { jest lepsze niż skupianie się na popeł- } \\
\text { nianych przez niego błędach. }\end{array}$ & 4,33 & 0,84 & 4,60 & 0,65 & $7,18^{* *}$ & 0,34 & $B>A$ \\
\hline $\begin{array}{l}\text { 4. Rodzice nie muszą wiedzieć wszyst- } \\
\text { kiego o szkole. }\end{array}$ & 2,92 & 1,25 & 3,75 & 1,19 & $27,67^{\star \star \star}$ & 0,67 & $B>A$ \\
\hline $\begin{array}{l}\text { 5. Prace domowe powinny być zada- } \\
\text { wane jedynie dla chętnych i nie po- } \\
\text { winno to wpływać na ocenę ucznia. }\end{array}$ & 2,38 & 1,22 & 3,49 & 1,23 & $51,02^{\star \star * *}$ & 0,91 & $B>A$ \\
\hline $\begin{array}{l}\text { 6. Ważniejsza jest dobra atmosfera } \\
\text { w szkole, niż wyniki uczniów w nauce. }\end{array}$ & 3,24 & 1,20 & 3,67 & 1,06 & $8,39^{* *}$ & 0,97 & $B>A$ \\
\hline
\end{tabular}

Legenda: $\mathrm{ni}-p>0,05 ;{ }^{*} p<0,05 ;{ }^{* *} p<0,01 ;{ }^{* * *} p<0,01$.

Źródło: opracowanie własne. 
W trzeciej grupie znalazły się stanowiska i oceny zgłaszane przede wszystkim przez rodziców. Pokazują one, iż rodzice przenoszą na szkołę oczekiwania i odpowiedzialność za kształcenie i uczenie się ich dziecka. To szkoła, a dokładniej kompetentni nauczyciele, przede wszystkim odpowiadają za wyniki edukacyjne uczniów. $Z$ deklaracji wynika, że rodzice niekoniecznie skłonni są budować partnerskie relacje $\mathrm{z}$ nauczycielami. Znamienny jest sąd, iż szkoła nie musi wiedzieć wszystkiego o rodzinie, ale rodzina musi wiedzieć wszystko o szkole. Jest to stanowisko zgodne z zasadami funkcjonowania polskiej szkoły, widać w nim jednak brak symetrii między rodziną a szkołą. Siłę tego związku pokazuje tabela 3 .

Tabela 3. Stanowiska bardziej znaczące dla rodziców

\begin{tabular}{|c|c|c|c|c|c|c|c|}
\hline \multirow{2}{*}{ Stwierdzenie } & \multicolumn{2}{|c|}{ A: Rodzice } & \multicolumn{2}{|c|}{ B: Nauczyciele } & \multicolumn{3}{|c|}{ Porównanie średnich } \\
\hline & $\mathrm{M}$ & SD & $M$ & SD & $F(1 ; 334)$ & Siła efektu $d$ & Relacja A-B \\
\hline $\begin{array}{l}\text { 1. Nie ważne jaka jest szkoła, waż- } \\
\text { ne jacy są jej nauczyciele. }\end{array}$ & 3,98 & 1,07 & 3,70 & 1,22 & $3,96^{*}$ & 0,25 & $A>B$ \\
\hline $\begin{array}{l}\text { 2. To nauczyciel decyduje o tym jak } \\
\text { uczeń powinien się uczyć. }\end{array}$ & 3,04 & 1,10 & 2,73 & 1,31 & $4,42^{*}$ & 0,27 & $A>B$ \\
\hline $\begin{array}{l}\text { 3. Rolą nauczyciela jest wskazywać } \\
\text { uczniom popełniane błędy. }\end{array}$ & 3,79 & 1,10 & 3,31 & 1,20 & $11,40^{\star \star \star}$ & 0,43 & $A>B$ \\
\hline $\begin{array}{l}\text { 4. Szkoła odpowiada za wyniki } \\
\text { uczniów w nauce. }\end{array}$ & 3,67 & 0,99 & 3,22 & 1,13 & $11,89^{\star \star \star}$ & 0,44 & $A>B$ \\
\hline $\begin{array}{l}\text { 5. Bez pracy domowej nie ma do- } \\
\text { brego uczenia się. }\end{array}$ & 3,32 & 1,30 & 2,49 & 1,32 & $24,67^{\star \star \star}$ & 0,63 & $A>B$ \\
\hline $\begin{array}{l}\text { 6. Szkoła nie musi wiedzieć wszyst- } \\
\text { kiego o rodzinie, ale rodzic powinien } \\
\text { jak najwięcej wiedzieć o szkole. }\end{array}$ & 3,27 & 1,10 & 2,43 & 1,19 & $33,98^{\star \star \star}$ & 0,74 & $A>B ! ! !$ \\
\hline 7. Praca domowa jest częścią lekcji. & 3,56 & 1,28 & 2,53 & 1,34 & $38,42^{\star \star \star}$ & 0,79 & $A>B$ \\
\hline $\begin{array}{l}\text { 8. Nie da się zrealizować całego pro- } \\
\text { gramu nauczania na lekcji, do tego } \\
\text { potrzebna jest praca domowa. }\end{array}$ & 3,29 & 1,25 & 2,41 & 1,17 & $31,46^{\star \star \star}$ & 0,79 & $A>B$ \\
\hline
\end{tabular}

Legenda: ni $-p>0,05 ;{ }^{*} p<0,05 ;{ }^{* \star} p<0,01 ;{ }^{* \star \star} p<0,01$.

Źródło: opracowanie własne.

W kolejnym kroku przeprowadzono analizę czynnikową. Analiza czynnikowa to cała rodzina technik pozwalająca na przedstawienie relacji między zmiennymi należącymi do tego samego zbioru (Wieczorkowska, Wierzbiński 2007, s. 317).

Zanim jednak wykonano analizę czynnikową, należało upewnić się, że dane wprowadzone do analizy spełniają założenia pozwalające na właściwą interpretację czynników oraz dokonywanie dalszych analiz (predykcji) z ich wykorzystaniem. W tym celu zastosowano współczynniki testujące właściwości macierzy korelacji: KMO oraz test sferyczności Bartletta, aby zorientować 
się, czy można przeprowadzić analizę czynnikową (Bedyńska, Brzezicka 2007, s. $140-141)$.

Miara KMO (Kaiser-Meyer-Olkin Measure of Sampling Adequancy), to: „stosunek wielkości korelacji zmiennych do wielkości korelacji częściowej tych zmiennych". Wartość tego wskaźnika zawiera się w przedziale (0 do 1), gdzie wartość bliższa 1 daje możliwość przeprowadzenia analizy czynnikowej. Taką samą informację niesie test sferyczności Bartletta (Wieczorkowska, Wierzbiński 2007, s. 321-323). Zatem dane doskonale nadawały się do analizy, o czym świadczyła wysoka wartość współczynnika KMO = 0,799 oraz testu sferyczności Bartletta 3862,98; $\mathrm{df}=780 ; \mathrm{p}<0,001$. Przeprowadzona analiza wykazała istnienie trzech czynników, na co wyraźnie wskazuje wykres osypiska (wykres 1).

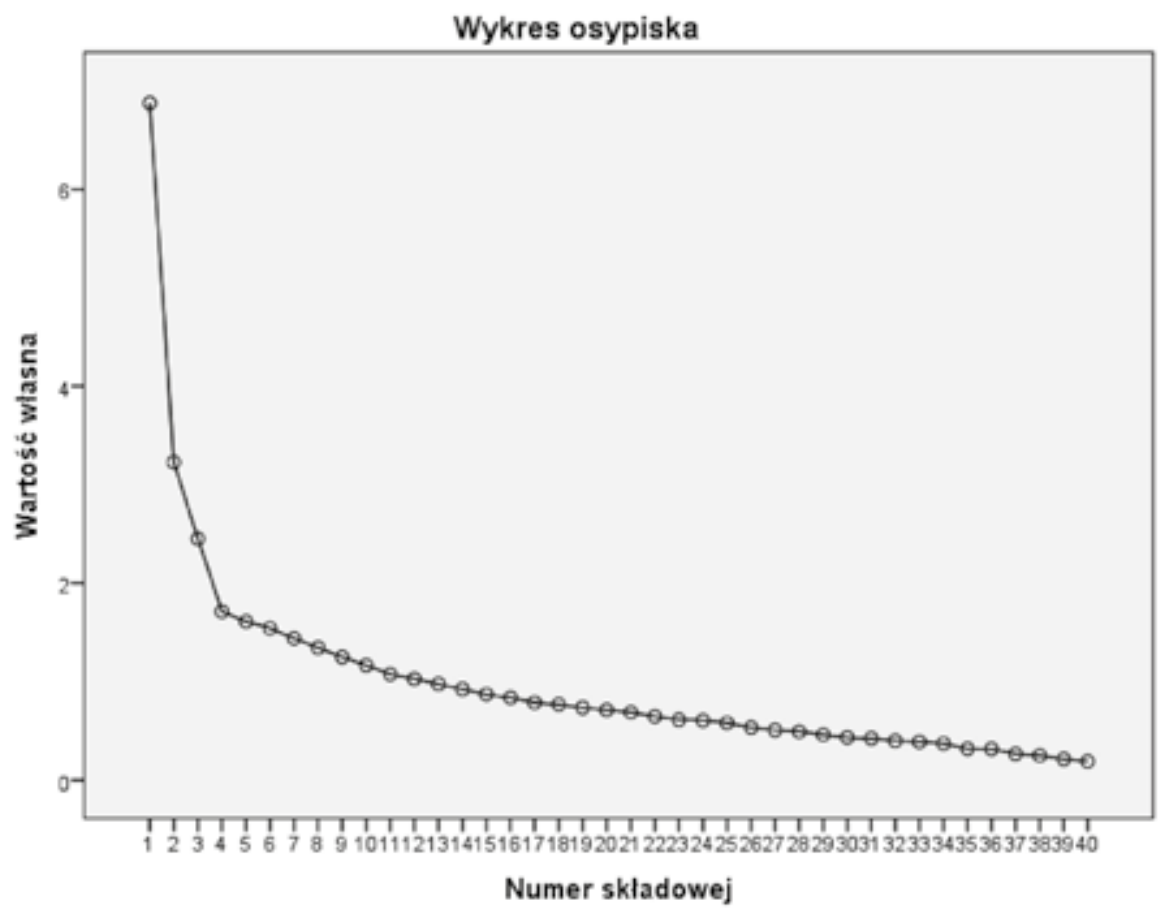

Wykres 1. Wykres osypiska

Posługiwanie się wykresem osypiska przy określaniu liczby czynników jest szczególnie korzystne wtedy, gdy ankieta zawiera dużo pytań i istnieje ryzyko pojawienia się dużej liczby czynników, ale za to niezbyt silnych. Wykres osypiska daje możliwość ograniczenia liczby czynników. Na wykresie w postaci kółek zaznaczone są poszczególne czynniki (ich numery znajdują się na osi poziomej - osi X) oraz ich wartości własne (na pionowej osi Y). Wartości 
własne pozwalają na określenie liczby czynników. Zgodnie z tym kryterium, uwzględnia się tyle czynników, ile jest na „stromiźnie" wykresu. W punkcie, gdzie wykres przestaje być stromy, oznacza się liczbę czynników ( Bedyńska, Brzezicka 2007, s. 144-145).

Przeprowadzona analiza wykazała trójczynnikową strukturę poglądów nauczycieli i rodziców na temat nauczania i wychowania. Czynnik pierwszy, który został nazwany „Konserwatywne poglądy na temat nauczania i dyscypliny w szkole”, tworzyło 15 stwierdzeń. Czynnik drugi - „Poglądy na temat partnerstwa w szkole i poszanowania indywidualności ucznia" - tworzyło 11 stwierdzeń. Czynnik trzeci, „Poglądy na temat zadawnia prac domowych”, tworzyło sześć stwierdzeń. Należy zwrócić uwagę, że dwa $\mathrm{z}$ nich były ujemnie skorelowane $\mathrm{z}$ treścią czynnika i $\mathrm{w}$ dalszej analizie zostały odwrócone.

W kolejnym etapie na podstawie wyników analizy czynnikowej metodą uśredniania utworzono trzy skale, będące odwzorowaniem trzech poglądów na temat nauczania i wychowania. Spójność wewnętrzna utworzonych w ten sposób skal okazała się być w pełni akceptowalna (tab. 9).

Tabela 4. Poglądy rodziców i nauczycieli na temat nauczania i wychowywania - charakterystyka opisowa

\begin{tabular}{|c|c|c|c|c|c|c|c|c|}
\hline \multicolumn{2}{|c|}{ Czynnik } & \multicolumn{4}{|c|}{ Statystyki opisowe } & \multicolumn{3}{c|}{ Korelacje } \\
\cline { 2 - 8 } & Min. & Max & M & SD & A & B & C \\
\hline A & $\begin{array}{l}\text { Konserwatywne poglą- } \\
\text { dy na temat nauczania } \\
\text { i dyscypliny w szkole. }\end{array}$ & 1,73 & 5,00 & 3,38 & 0,62 & $\alpha=0,83$ & $-0,09$ (ni) & $0,41^{\text {** }}$ \\
\hline B & $\begin{array}{l}\text { Poglądy na temat part- } \\
\text { nerstwa w szkole i po- } \\
\text { szanowania indywidual- } \\
\text { ności ucznia. }\end{array}$ & 3,00 & 5,00 & 4,21 & 0,44 & $\alpha=0,68$ & $-0,21^{\text {*** }}$ \\
\hline C & $\begin{array}{l}\text { Poglądy na temat zada- } \\
\text { wania prac domowych. }\end{array}$ & 1,00 & 5,00 & 3,05 & 0,97 & & & $\alpha=0,83$ \\
\hline
\end{tabular}

Legenda: ni $-p>0,05 ;{ }^{\star * \star} p<0,01$.

Źródło: opracowanie własne.

Tabela 5. Porównanie poglądów na temat nauczania i wychowywania

\begin{tabular}{|l|c|c|c|c|c|c|c|}
\hline \multirow{2}{*}{ Pogląd } & \multicolumn{2}{|c|}{ A: Rodzice } & B: Nauczyciele & \multicolumn{3}{|c|}{ Porównanie średnich } \\
\cline { 2 - 8 } & $\mathrm{M}$ & SD & $\mathrm{M}$ & SD & $F(1 ; 334)$ & Siła efektu $d$ & Relacja A-B \\
\hline $\begin{array}{l}\text { Konserwatywne poglądy na temat } \\
\text { nauczania i dyscypliny w szkole. }\end{array}$ & 3,40 & 0,59 & 3,31 & 0,69 & 1,42 (ni) & 0,15 & \\
\hline $\begin{array}{l}\text { Poglądy na temat partnerstwa } \\
\text { W szkole i poszanowania indywidu- } \\
\text { alności ucznia. }\end{array}$ & 4,17 & 0,44 & 4,34 & 0,40 & $9,64^{\star \star}$ & 0,39 & B > A \\
\hline $\begin{array}{l}\text { Poglądy na temat zadawania prac } \\
\text { domowych. }\end{array}$ & 3,25 & 0,92 & 2,44 & 0,87 & $49,42^{\star \star \star}$ & 0,89 & $\mathrm{~A}>\mathrm{B}$ \\
\hline
\end{tabular}

Legenda: ni $-p>0,05 ;{ }^{* *} p<0,01$; ${ }^{* \star} p<0,01$.

Źródło: opracowanie własne. 
Przeprowadzone analizy wykazały, że rodzice nie różnią się w swoich poglądach od nauczycieli na temat nauczania i dyscypliny w szkole [F $(1 ; 334)$ $=1,42 ; p<0,05 ; \mathrm{d}=0,15]$. To stanowisko $\mathrm{w}$ równym stopniu cenią rodzice i nauczyciele. Nauczyciele cenią wyżej niż rodzice partnerstwo w szkole i poszanowanie indywidualności ucznia $[\mathrm{F}(1 ; 334)=9,64 ; p<0,01 ; \mathrm{d}=0,39]$. Różnice między średnimi utrzymują się na średnim poziomie. Pogłębione analizy wykazały, że to rodzice są bardziej przekonani o konieczności zadawania prac domowych niż nauczyciele $[\mathrm{F}(1 ; 334)=49,42 ; p<0,05 ; \mathrm{d}=0,15]$. W tym zakresie różnicę między średnimi należy uznać za dużą. Okazała się ona znamienna i szczególnie ważna dla powodzenia całego projektu innowacyjnego. Dla szkoły i nauczycieli niezadawanie prac domowych było traktowane w środowisku lokalnym jako znak rozpoznawczy placówki. Także zdaniem części rodziców był to fundament programu. A jednak ich ocena okazała się inna. Jak widać przeważał jednak głos tych, którzy konsekwentnie opowiedzieli się za zachowaniem tradycyjnej praktyki odrabiania zadań domowych.

\section{Podsumowanie}

Wyniki przeprowadzonego badania skłaniają do następujących wniosków. Po pierwsze, cząstkowe badania pokazują, że grupą dominującą popierającą innowacje pedagogiczne okazali się przede wszystkim nauczyciele. To oni zgłaszali różnorodne inicjatywy, tworzyli projekty badawcze. Byli w pierwszej kolejności pomysłodawcami i realizatorami projektu pod nazwą „Budząca się szkoła”. Wspólnie z dyrekcją szkoły wykazali się inicjatywą, poczuciem sprawstwa i misją nastawionymi na rozwój i doskonalenie jakości pracy szkoły. Badania pokazały, iż nauczyciele stawiają ucznia w centrum zainteresowania. Szukają przede wszystkim jego mocnych stron. Mają poczucie odpowiedzialności za edukację i wychowanie dzieci. Dostrzegają trudności i przeszkody w prowadzeniu programu innowacyjnego, widzą wstrzemięźliwość, a nawet niechęć części rodziców. Skłonni są jednak widzieć w tym programie szanse rozwoju ucznia. Pojednawczo przekonują, że prace domowe powinny być zadawane, choć mogą być tylko dla chętnych. Zdaniem nauczycieli motywacja, ciekawość poznawcza jest ważniejsza niż wyniki w nauce.

Po drugie, wprowadzany przez szkołę projekt innowacyjny ujawnił niezbyt widoczną i silną gotowość do współpracy, komunikacji między nauczycielami a rodzicami, a także wspólną odpowiedzialność za powodzenie projektu. Choć ujawnił się wyraźny obszar wspólnych stanowisk i ocen związanych $\mathrm{z}$ nauczaniem, funkcjonowaniem szkoły, wprowadzaniem innowacyjnych projektów, równie wyraziste było pole rozbieżności. Zarówno nauczyciele jak i ro- 
dzice dość jednoznacznie, czasami kontrowersyjnie, formułowali swoje stanowiska i sądy. Obie strony prezentowały raczej konserwatywne poglądy na temat nauczania i dyscypliny szkolnej. Stanowisko rodziców było jednak bardziej tradycyjne, oparte na takich wartościach, jak: porządek społeczny, hierarchia, autorytet.

Badania ujawniły, iż rodzice mają duże oczekiwania wobec szkoły, ale nie są zbyt skorzy angażować się w działania ją ulepszające. Skupiają się na wynikach $\mathrm{w}$ nauce, pomijając często pytania o zindywidualizowane potrzeby i możliwości własnego dziecka. Na podstawie badań trudno mówić o wyraźnym partnerstwie rodziców i nauczycieli. Nie oznacza to jednak odrzucenia tego partnerstwa i braku gotowości do jego budowania przez obie strony. Między rodzicami a nauczycielami pojawiło się wiele niejasności, niezrozumienia, niedomówień, a nawet sprzeczności. Dotyczyło to jednak wybranych elementów, a zwłaszcza odrabiania zajęć domowych. Rodzice nie byli przygotowani, przekonani, do rezygnacji z prac domowych. Paradoksalnie odbierali to jako obniżenie wymagań szkolnych, obniżenie poziomu edukacji, wreszcie brak kontroli nad uczeniem się własnego dziecka. Te różnorodne, czasami zaskakujące argumenty, na szczęście nie różnicowały zbytnio środowiska rodzicielskiego i nauczycielskiego. I rodzice, i nauczyciele starali się zachowywać płaszczyznę komunikacji i dialogu. Chronili i szanowali partnerską przestrzeń dialogu i kompromisu. Odpowiedzią ze strony nauczycieli było skorygowanie programu i budowania alternatywnych rozwiązań. Prace domowe powróciły do praktyki szkolnej jako zróżnicowane zindywidualizowane zadania dostosowane do poszczególnych uczniów.

Przeprowadzone badania pokazały, iż wykształceni wielkomiejscy rodzice prezentują raczej konserwatywny model edukacji. Są bardziej zachowawczy niż młodzi wykształceni nauczyciele. To rodzice nie dowierzają szkolnym innowacjom, dystansują się wobec nich, zasłaniają się brakiem znajomości progra$\mathrm{mu}$, niedostatecznie wyartykułowaną zgodą na propozycje szkoły. Ich różnorodne sądy i oceny trafiają na ogół w otwartą przestrzeń szkolnej komunikacji i dialogu. Stwarza ona możliwość budowania partnerstwa opartego na wspólnocie idei, wspólnocie działania i odpowiedzialności. Jak pokazały badania grupą inicjatywną partnerstwa rodziny i szkoły są w pierwszej kolejności nauczyciele. To oni są bardziej skłonni do innowacji, wprowadzania alternatywnych rozwiązań edukacyjnych.

Dalsze losy projektu, jego powodzenie, wymagają bliższej, otwartej komunikacji, rozszerzonego działania i współodpowiedzialności zarówno rodziców jak i nauczycieli za doraźne i bardziej odległe efekty pracy. Praktyka pokazuje jednak, że w polskiej rzeczywistości coraz silniej wybrzmiewa głos 
trzeciego partnera, którym jest państwo. Pytanie, na ile ten partner potrafi rzeczywiście budować partnerskie relacje między różnymi podmiotami środowiska szkolnego?

\section{Literatura}

Bakiera L. (2013), Zaangażowane rodzicielstwo a autokreacyjny aspekt rozwoju dorostych, Warszawa: Difin.

Bedyńska S., Brzezicka A. (2007), Statystyczny drogowskaz. Praktyczny poradnik analizy danych $w$ naukach społecznych na przykładach $z$ psychologii, Warszawa: Wyd. SWPS ACADEMICA.

Czerepaniak-Walczak M. (2010), Wychowanie: pojęcia, procesy, konteksty: interdyscyplinarne ujęcie. T.5 Codzienność w szkole, szkoła w codzienności, Gdańsk: GWP.

Dalin P. (1985), Organisationsentwicklung als Beitrag zur Schulentwicklung. Innovationstrategien fur die Schule, Munchen.

Epstein J.L. (1995), School/Family/Community Partnerships. Caring for the Children We Share, Phi Delta Kappan.

Fishel M., Ramirez L. (2005), Evidence-based parent involvement interventions with school-aged children, „School Psychology Quarterly”, 20(4), 371-402.

Fullan M. (1991), The new meaning of educational change, New York.

Hill N.E., Tyson D.F. (2009), Parental involvement in middle school: a meta-analytic assessment of the strategies that promote achievement, „Developmental Psychology”, 45(3), 740-763.

Kowalski S. (1969), Szkoła w środowisku, Warszawa: PZWS.

Mendel M. (1999), Edukacja społeczna - odmiana myślenia o wczesnej edukacji, Olsztyn: Wydawnictwo OSW.

Mendel M. (2002), Edukacja społeczna. Partnerstwo rodziny, szkoly i gminy w perspektywie amerykańskiej, Toruń: Wydawnictwo Adam Marszałek.

Modrzewski J. (1989), Środowisko społeczne młodzieży studiującej, Poznań: Wydawnictwo UAM.

Nowosad I. (2003), Perspektywy rozwoju szkoły. Szkice z teorii szkoły, Warszawa: Instytut Badań Edukacyjnych.

Nowosad I., Sander A. (red.) (2009), Szkoła w Niemczech. Rozwój, autonomia, środowisko, Toruń: Wydawnictwo Adam Marszałek.

Pilch T. (1995), Środowisko lokalne - struktura, funkcje, przemiany, [w:] T. Pilch, I. Lepalczyk (red.), Pedagogika Społeczna, Warszawa: Wydawnictwo Naukowe ŻAK.

Radlińska H. (1935), Stosunek wychowawczy do środowiska społecznego. Szkice z pedagogiki spoŁecznej, Warszawa: „Nasza Księgarnia”.

Radziewicz-Winnicki A. (1996), Uczestnictwo w kulturze społeczności lokalnej, [w:] T. Frąckowiak (red.), Koncepcje pedagogiki społecznej, Poznań: Uniwersytet im. Adama Mickiewicza.

Schulz R. (1992), Szkoła jako organizacja, Toruń: Uniwersytet Mikołaja Kopernika.

Smolińska-Theiss B., Theiss W. (2019), Pedagogika społeczna, [w:] Z. Kwieciński, B. Śliwerski (red.), Pedagogika, Warszawa: PWN.

Szumski G., Karwowski M. (red.) (2015), Rodzicielskie zaangażowanie w naukę gimnazjalistów sprawnych i ze specjalnymi potrzebami edukacyjnymi, „Edukacja”, 4(135), 91-106.

Śliwerski B. (2008), Klinika szkolnej demokracji, Kraków:Oficyna Wydawnicza Impuls.

Tillmann K.J. (red.) (1987), Theorie der Schule - eine Einführung, [w:] Bergamann und Helbig, Schultheorien. Hamburg. 
Theiss W. (2018), Helena Radlińska: powrót do źródet i tradycji w ponowoczesnym świecie, „Pedagogika Społeczna", 4, 113-123.

Trempała E. (1976), Wychowanie zintegrowane w środowisku szkoły, Warszawa: WSiP.

Wieczorkowska G., Wierzbiński J. (2007), Statystyka. Analiza badań społecznych, Warszawa: Wydawnictwo Naukowe Scholar.

Winiarski M. (1975), Wychowanie integralne a szkoła środowiskowa, Warszawa: Książka i Wiedza.

European Research Network About Parents in Education ERNAPE 